PUSTABIBLIA: Journal of Library and Information Science

ISSN 2549-3493 (Print); ISSN 2549-3868 (Online)

DOI: http://dx.doi.org/10.18326/pustabiblia.v5i2.299-322

SK Dirjen Risbang-Kemristekdikti No 23/E/KPT/2019 (Peringkat 4 SINTA)

\title{
Dampak Pandemi Covid-19 Terhadap User Experience pada Perpustakaan Digital
}

\author{
Orisa Mahardhini, Indira Irawati \\ Departemen Ilmu Perpustakaan dan Informasi, Fakultas Ilmu Budaya, \\ Universitas Indonesia, Depok, 15424, Indonesia \\ Email: orisa.mahardhini@ui.ac.id, indirairawati2010@gmail.com
}

Naskah diterima: 04-10-2021, direvisi: 05-11-2021, disetujui: 07-11-2021

\begin{abstract}
The user interface of digital libraries during the special conditions of the COVID-19 pandemic is one of the leading indicators that need attention from libraries. Library users will always choose easy access, fast and recommended by library users by word of mouth. The User Interface will affect the user experience in using the digital library. This research is essential to find out the description of user experience in using digital libraries during the COVID-19 pandemic. This study aims to describe the user experience, which includes emotions, perceptions, attitudes, and responses in using digital libraries. This study uses a qualitative approach with a systematic literature review method using the Systematic Literature Review (SLR) software guide from Kitchenham. User experience in using digital libraries is influenced by emotions and perceptions of digital library users because the urgency of using digital library services is increasingly substantial during the pandemic. In conclusion, the impact of the COVID-19 pandemic has affected the user experience, especially in the crisis that has created user awareness to use digital libraries. Considering that research related to User Experience in digital libraries during the COVID-19 pandemic is still lacking, the researchers suggest that further research be carried out with a quantitative approach to obtain valid data.
\end{abstract}




\begin{abstract}
Abstrak
Desain User Interface perpustakaan digital selama kondisi khusus pandemi COVID-19, menjadi salah satu leading indicator yang perlu mendapat perhatian dari perpustakaan. Pengguna perpustakaan akan selalu memilih akses yang mudah, cepat dan direkomendasikan oleh pengguna perpustakaan dari mulut ke mulut. Antarmuka Pengguna akan mempengaruhi pengalaman pengguna dalam menggunakan perpustakaan digital. Penelitian ini penting dilakukan untuk mengetahui gambaran pengalaman pengguna dalam menggunakan perpustakaan digital selama masa pandemi COVID-19. Penelitian ini bertujuan untuk mendeskripsikan pengalaman pengguna yang meliputi emosi, persepsi, sikap, dan tanggapan dalam menggunakan perpustakaan digital. Penelitian ini menggunakan pendekatan kualitatif dengan metode systematic literature review menggunakan software Systematic Literature Review (SLR) guide dari Kitchenham. Pengalaman pengguna dalam menggunakan perpustakaan digital dipengaruhi oleh emosi dan persepsi pengguna perpustakaan digital karena urgensi penggunaan layanan perpustakaan digital semakin substansial di masa pandemi. Disimpulkan bahwa dampak dari pandemi COVID-19 telah mempengaruhi pengalaman pengguna, terutama dalam krisis yang telah menciptakan kesadaran pengguna untuk menggunakan perpustakaan digital. Mengingat penelitian terkait user experience di perpustakaan digital pada masa pandemi COVID-19 masih kurang, maka peneliti menyarankan agar dilakukan penelitian lebih lanjut dengan pendekatan kuantitatif untuk mendapatkan data yang valid.
\end{abstract}

Keywords: $\quad$ User Experience; Digital Libraries; The COVID-19 pandemic

\title{
1. PENDAHULUAN
}

Berbicara mengenai pengalaman pengguna (User Experience) tidak jauh berbicara mengenai arsitektur informasi (Information Architecture), desain antar muka (User Interface), serta ketergunaannya (Usability). User Experience yang positif penting untuk diterapkan dalam sebuah perpustakaan digital. Hariri dan Norouzi merekomendasikan 22 kriteria evaluasi antarmuka perpustakaan digital diantaranya navigasi, kolom pencarian, konsistensi, kemudahan penggunaan, dan sebagainya. ${ }^{1}$ Hal tersebut dapat

${ }^{1}$ Nadjla Hariri and Yaghoub Norouzi. 2011. "Determining Evaluation Criteria for Digital Libraries’ User Interface: A Review.” Electronic Library 29 (5): 698-722. https://doi. org/10.1108/02640471111177116. 
diartikan bahwa, kemudahan dalam mengakses perpustakaan digital penting dalam meningkatkan pengalaman pengguna (User Experience). Selama pandemi COVID-19, pengguna perpustakaan akan selalu memilih akses informasi yang mudah, cepat dan direkomendasikan oleh kalangan pengguna perpustakaan dari mulut ke mulut. Desain antar muka (User Interface) akan mempengaruhi pengalaman pengguna (User experience) dalam keterlibatannya menggunakan perpustakaan digital.

Adanya aturan pembatasan secara fisik akibat dari pandemi COVID-19 yang menyebabkan perpustakaan harus menutup layanan secara fisik namun tetap dituntut untuk memberikan layanan secara online, mengakibatkan perpustakaan harus memutar otak agar kebutuhan pengguna tetap terpenuhi dengan bantuan teknologi digital. Hal tersebut tidak sedikit membuat perpustakaan kelabakan, terutama bagi perpustakaan dengan kondisi yang terbatas dalam memberikan akses ke koleksi digital. Di era digital seperti sekarang ini, seharusnya hal tersebut tidak menjadi persoalan yang berarti bagi perpustakaan dalam menyediakan akses informasi secara digital. Perpustakaan dapat memanfaatkan teknologi digital tersebut untuk mengembangkan perpustakaan digital yang tentu saja disesuaikan dengan kebutuhan dan karakteristik pengguna perpustakaanya.

Kondisi pandemi COVID-19 tersebut telah mengubah cara pengguna perpustakaan menggunakan teknologi digital khususnya dalam mengakses informasi. Selama masa pandemi COVID-19, pengguna perpustakaan cenderung mengakses informasi secara online melalui sumber-sumber terbuka seperti open access journal maupun ebook melalui website ketika mereka tidak dapat mengakses perpustakaan. Kecenderungan seperti ini harus segera disikapi oleh perpustakaan dengan menyediakan perpustakaan digital. Dengan adanya perpustakaan digital memudahkan pengguna perpustakaan mengakses sumber-sumber informasi yang valid dan relevan, serta dapat mengaksesnya dari mana saja, kapan saja tidak terbatas ruang dan waktu tanpa harus datang ke perpustakaan sehingga mengurangi penyebaran virus corona. 
Penelitian mengenai dampak pandemi COVID-19 terhadap pengalaman pengguna (User Experience) terutama dalam dunia perpustakaan belum banyak dilakukan di Indonesia. Adapun tujuan dari penelitian ini adalah untuk mendeskripsikan pengalaman pengguna (User experience) yang meliputi emosi, persepsi, sikap dan respon dalam menggunakan perpustakaan digital. Berdasarkan latar belakang tersebut, penelitian ini bermaksud ingin mengetahui lebih lanjut mengenai: Bagaimana dampak pandemi COVID-19 terhadap pengalaman pengguna (User Experience) dalam menggunakan digital library?

\section{TINJAUAN PUSTAKA}

Berangkat dari penelitian terdahulu dengan topik pembahasan yang sama namun dengan objek yang berbeda, diharapkan dapat memperkaya khazanah penelitian mengenai pandemi COVID-19 terhadap perpustakaan khususnya mengenai pengalaman pengguna (User Experience). Penelitian pertama diambil dari penelitian Moreira dengan judul The impact of the COVID-19 pandemic on User Experience Design of Digital Platforms. ${ }^{2}$ Penelitian ini menggunakan metode mixed method (kualitatif dan kuantitatif), bertujuan untuk mengetahui perubahan pengalaman pengguna pada platform digital dengan. Hasil penelitian Moreira mengungkapkan bahwa perilaku pengguna dan pemahaman pelanggan disaat krisis akan membantu perusahaan di masa depan untuk dapat menangani berbagai situasi krisis di masa depan.

Penelitian kedua diambil dari Barifah, Landoni dan Eddakrouri dengan judul Evaluating the User experience in a Digital Library. 3 Penelitian ini menggunakan metode eksperimen dengan hasil penelitian yaitu dengan meneliti aspek pengalaman pengguna memberi pemahaman yang lebih baik tentang user experience dibanding studi kegunaan. Penelitian ketiga dari

\footnotetext{
${ }^{2}$ Inna Narciso Moreira. 2021. "The Impact of the COVID-19 Pandemic on User Experience Design of Digital Platforms."

${ }^{3}$ Maram Barifah, Monica Landoni, and Ayman Eddakrouri. 2020. "Evaluating the User Experience in a Digital Library." Proceedings of the Association for Information Science and Technology 57 (1): 1-17. https://doi.org/10.1002/pra2.280.
} 
Sasongko, Ferdiana dan Hartanto dengan judul The Development of Digital Library User Interface by Using Responsive Web Design and User Experience. 4 Metode yang digunakan dalam penelitian ini adalah metode pengujian user experience untuk evaluasi antarmuka perpustakaan digital dan responsive web design untuk pengembangan antarmuka perpustakaan digital. Hasil penelitian ini adalah implementasi user experience dan responsive web design pada perancangan antarmuka perpustakaan digital dapat meningkatkan estimasi presentase keberhasilan dan waktu akses pengguna.

Pada fase awal pada pertengahan 1990-an perpustakaan digital digambarkan sebagai "perpustakaan elektronik", "perpustakaan virtual”, "perpustakaan yang dapat diakses jaringan", atau "perpustakaan tanpa dinding", dsb. Association of Research Libraries (ARL) memberikan salah satu definisi awal perpustakaan digital berdasarkan pada buku Karen Drabenstott, Analytical Review of the Library of the Future, di terbitkan tahun 1994 mendefinisikan elemen umum perpustakaan digital yaitu bukanlah satu kesatuan; membutuhkan teknologi untuk menghubungkan banyak sumber daya; hubungan antara perpustakaan digital dan layanan informasi transparan nagi pengguna perpustakaan; tujuannya adalah akses universal ke perpustakaan digital dan layanan informasi; koleksi tidak terbatas dokumen pengganti, meluas ke artefak digital yang tidak dapat direpresentasikan atau didistribusikan dalam format cetak. ${ }^{5}$

Pendapat lain mengungkapkan perpustakaan digital merupakan kumpulan informasi yang terorganisir dengan layanan yang didukung dan tempat di mana informasi disimpan dalam format digital dan dapat diakses menggunakan jaringan internet ${ }^{6}$. Selanjutnya dalam artikel Thaker disebutkan

${ }^{4}$ Dimas Sasongko, Ridi Ferdiana, and Rudy Hartanto. 2016. "The Development of Digital Library User Interface by Using Responsive Web Design and User Experience." Indonesian Journal of Electrical Engineering and Computer Science 4 (1): 195-202. https://doi.org/10.11591/ijeecs.v4.i1. pp195-202.

${ }^{5}$ Iris Xie and Krystyna K. Matusiak. 2016. Discover Digital Libraries: Theory and Practice. Discover Digital Libraries: Theory and Practice.

${ }^{6}$ Kinnery Thaker and Pratiksinh S. Vaghela. 2017. "Digital Library and User's Experience: A Literature Review." Scientific Society of Advanced Research and Social Change SSARSC International Journal of Library, Information Networks and Knowledge 2 (1): 1-8. 
perpustakaan digital terdiri dari konten digital yang saling terhubung dengan tautan, metadata atau database dan perangkat lunak dengan menggunakan basic page pada HTML atau berdasarkan pada sistem manajemen database.

Perpustakaan digital sendiri telah lama mendapat perhatian dari UNESCO sebagai organisasi pendidikan, ilmu pengetahuan dan kebudayaan dengan mengesahkan manifesto IFLA untuk perpustakaan digital pada General Conference tahun 2011. Manifesto tersebut bertujuan untuk membantu perpustakaan dalam melakukan kegiatan digitalisasi yang berkelanjutan dan dapat dioperasikan untuk menjembatani kesenjangan digital. ${ }^{7}$ Lebih lanjut IFLA/UNESCO Manifesto for Digital Libraries mendefinisikan perpustakaan digital sebagai koleksi online objek digital, dengan kualitas terjamin, yang dibuat atau dikumpulkan dan dikelola sesuai dengan prinsip yang diterima secara internasional untuk pengembangan koleksi dan dapat diakses secara koheren dan berkelanjutan, didukung oleh layanan yang diperlukan untuk memungkinkan pengguna mengambil dan mengeksploitasi sumber daya.

Dengan demikian kumpulan informasi dalam satu halaman web tidak serta merta dapat dikatakan sebagai perpustakaan digital. Perpustakaan digital membutuhkan dukungan teknologi untuk menghubungkan sumber daya dari banyak layanan yang disebarluaskan kepada pengguna. Pengumpulan informasi tidak terbatas pada penyimpanan dokumen saja tetapi lebih luas lagi hingga ke artefak digital yang hanya dapat didistribusikan dalam format digital.

ISO 9241-210 mendefinisikan User experience sebagai pengalaman pengguna yang mencakup semua emosi, keyakinan, preferensi, persepsi, fisik dan tanggapan psikologis pengguna, perilaku, dan pencapaian yang terjadi sebelum, selama, dan setelah penggunaa. Lebih lanjut dijelaskan User experience merupakan konsekuensi dari presentasi, fungsionalitas, kinerja sistem, perilaku interaktif, dan kemampuan bantuan dari sistem interaktif, baik perangkat keras, maupun perangkat lunak. Jika dilihat dari perspektif pribadi pengguna, User experience mencakup persepsi dan emosional serta

${ }^{7}$ IFLA. 2011. "UNESCO Endorses the IFLA Manifesto for Digital Libraries.” 2011. https:// www.ifla.org/news/unesco-endorses-the-ifla-manifesto-for-digital-libraries/ 
kepuasan kerja dan penghapusan monoton dari sebuah sistem.

Berikut empat fitur utama pendekatan User Experience yaitu: 1) User experience bersifat subjektif dan muncul dari pennggunaan teknologi; 2) User experience bertujuan perspektif secara keseluruhan, termasuk kepentingan dalam faktor non-utilitarian (tidak bermanfaat); 3) emosi merupakan sepenuhnya terintegrasi ke dalam pengalaman subjektif; 4) sifat pengalaman pengguna berkembang dari waktu ke waktu ${ }^{8}$ Lebih lanjut Linden menjelaskan mengenai model Components of User experience (CUE-model) yang diusulkan oleh Thüring \& Mahlke yaitu model yang menggabungkan beberapa fitur User experience. Model ini dibangun berdasarkan temuan penelitian empiris pada smartphone dan audio player dan cocok untuk penelitian empiris tentang teknologi inovatif dan menguji efek eksternal pada aspek pengalaman pengguna.

Dalam CUE-Model, aspek inti dari pengalaman pengguna diringkas dalam tiga komponen berbeda yaitu: 1) kualitas instrument yang dirasakan (perceived instrumental qualities) komponen ini mengambil manfaat yang dirasakan dan kemudahan penggunaan yang dirasakan sebagai elemen utama yang membentuk komponen; 2) kualitas non-instrumental yang dirasakan (perceived instrumental qualities) berkaitan dengan aspek teknologi yang tidak penting untuk kinerja tugas tetapi untuk keinginan dan kebutuhan pribadi pengguna. Mencakup penilaian estetika dan sibolik dan motivasi yang membentuk kapasitas yang berhubungan erat dengan teknologi untuk memotivasi penggunanya; 3) reaksi emosi (emotional reactions), komponen ini diteorikan sebagai konsekuensi emosional yang berasal dari dua komponen sebelumnya. Ketiga komponen pengalaman pengguna memungkinkan seseorang untuk terbentuk penilaian keseluruhan dan menentukan perilaku penggunaan teknologi. Lebih lanjut CUE-Model dapat dilihat pada Gambar 1 berikut:

${ }^{8}$ Jan Van Der Linden and others 2019. "User Experience and Social Influence: A New Perspective for UX Theory." Lecture Notes in Computer Science (Including Subseries Lecture Notes in Artificial Intelligence and Lecture Notes in Bioinformatics) 11583 LNCS: 98-112. https://doi. org/10.1007/978-3-030-23570-3_9. 


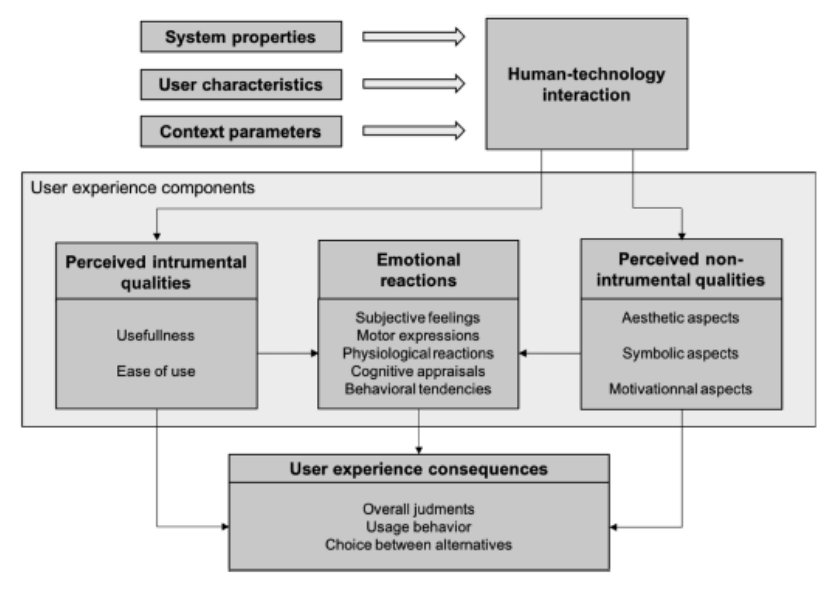

Fig. 1. CUE-model

\section{Gambar 1. CUE-model}

Sumber: (Van Der Linden et al. 2019) ${ }^{9}$

Bevan sebagaimana dikutip oleh Linden, mengatakan bahwa pengalaman pengguna berfokus pada preferensi pengguna, persepsi, emosi dan respon fisik dan psikologis yang terjadi sebelumnya, selama dan setelah menggunakan teknologi. Sementara, kegunaan biasanya berkaitan dengan tujuan bersama oleh kelompok pengguna atau pengalaman pengguna yang bersangkutan sesuai dengan tujuan masing-masing, yang dapat mencakup motivasi pribadi termasuk kebutuhan untuk memperoleh pengetahuan dan keterampilan baru, mengkomunikasikan identitas pribadi dan untuk memprovokasi kenangan yang menyenangkan. Pengalaman pengguna juga menekankan bagaimana pengalaman berubah dengan penggunaan berulang. ${ }^{10}$

${ }^{9}$ Jan Van Der Linden and others 2019. "User Experience and Social Influence: A New Perspective for UX Theory." Lecture Notes in Computer Science (Including Subseries Lecture Notes in Artificial Intelligence and Lecture Notes in Bioinformatics) 11583 LNCS: 98-112. https://doi. org/10.1007/978-3-030-23570-3_9.

${ }^{10}$ Nigel Bevan, James Carter, and Susan Harker. 2015. "Iso 9241-11 Revised: What Have We Learnt about Usability since 1998?” Lecture Notes in Computer Science (Including Subseries Lecture Notes in Artificial Intelligence and Lecture Notes in Bioinformatics) 9169: 143-51. https:// doi.org/10.1007/978-3-319-20901-2_13. 


\section{METODE}

Penelitian ini menggunakan pendekatan kualitatif dengan metode tinjauan literatur sistematis menggunakan pedoman Systematic Literature Review (SLR) untuk perangkat lunak yang diadaptasi dari Kitchenham. Tahapan SLR tersebut meliputi planning, conducting dan reporting. Adapun manfaat dari melakukan literatur sistematis yaitu 1) memperdalam pengetahuan tentang sesuatu yang diteliti; 2) mengetahui hasil penelitian yang berhubungan dan yang sudah pernah dilaksanakan (related research); 3) mengetahui perkembangan ilmu pada bidang ilmu yang diminati (stateof-the-art);4) memperjelas masalah penelitian. ${ }^{11}$

\section{a. Planning}

\section{1) Identification Need for a Review}

Moreira menyebutkan pandemi COVID-19 telah merubah cara pengguna menggunakan platform dan layanan digital, layanan ini telah menjadi inti dari bagaimana orang berinteraksi dengan dunia luar. Penggunaan platform digital sebagai akibat dari situasi global yang memaksa pergeseran gaya hidup normal menjadi kenyataan yang hampir sepenuhnya menjadi online. Identifikasi kebutuhan terkait tinjauan literatur berdasarkan pada pengaruh pandemi COVID-19 terhadap perilaku pengguna (emosi, persepsi, sikap, respon) dalam menggunakan digital library. ${ }^{12}$

Mehta \& Wang dalam artikelnya menyebutkan pandemi COVID-19 telah mencipatakan kebutuhan akan informasi dan pengguna perpustakaan menyadari pentingnya layanan perpustakaan digital yang lebih dari sebelum masa pandemi. Perpustakaan digital menunjukan potensinya dengan menyediakan konten elektronik dan layanan online yang lebih kaya dan dengan kualitas tinggi. ${ }^{13}$

\footnotetext{
${ }^{11}$ Romi Satria Wahono. 2015. "Systematic Literature Review ( SLR )."

${ }^{12}$ Inna Narciso Moreira. 2021. "The Impact of the COVID-19 Pandemic on User Experience Design of Digital Platforms."

${ }^{13}$ Dipti Mehta and Xiaocan Wang. 2020. "COVID-19 and Digital Library Services - a Case Study of a University Library.” Digital Library Perspectives 36 (4): 351-63. https://doi.org/10.1108/ DLP-05-2020-0030.
} 


\section{2) Specifyig the Research Questions}

Struktur pertanyaan penelitian (research question) dengan menggunakan pendekatan PICOC yaitu Population (P): target grup dari investigasi; Intervention (I): aspek detail dari investigasi atau isu yang menarik bagi peneliti; Comparison (C): aspek dari investigasi akan dibandingkan dengan Intervention (I); Outcomes $(\mathrm{O})$ : efek dan hasil dari Intervention (I); Context (C): seting atau lingkungan dari investigasi. Pembatasan penelitian ini bertujuan untuk memberikan jawaban atas penelitian dengan spesifik. Adapun research question yang digunakan dalam penelitian ini dapat dilihat pada Tabel 1.

Tabel 1. Struktur Pertanyaan Penelitian PICOC

\begin{tabular}{ll}
\hline Population & User experience dan perpusakaan digital \\
\hline Intervention & $\begin{array}{l}\text { Pandemi Covid-19, emosi dan perasaan yang ditunjukan, } \\
\text { penggunaan perpustakaan digital }\end{array}$ \\
Comparison & User experience sebelum dan sesudah pandemi covid-19 \\
Outcomes & $\begin{array}{l}\text { Dampak pandemi covid-19, user experience, penggunaan } \\
\text { perpustakaan digital }\end{array}$ \\
Context & $\begin{array}{l}\text { Review dari hasil identifikasi terkait dampak pandemi covid-19 } \\
\text { dalam mempengaruhi perilaku pengguna menggunakan } \\
\text { perpustakaan digital }\end{array}$ \\
\hline
\end{tabular}
Sumber: Cruz-Benito $(2016)^{14}$

Berikut adalah Research Question (RQ) yang ditetapkan berdasarkan tabel di atas:

RQ1: Bagaimana dampak pandemi COVID-19 terhadap pengalaman pengguna (emosi, persepsi, sikap, respon) dalam menggunakan perpustakaan digital?

RQ2: Bagaimana kebutuhan pengguna saat ini terhadap perpustakaan digital dibandingkan sebelum masa pandemi?

${ }^{14}$ Juan Cruz-Benito. 2016. "Systematic Literature Review \& Mapping." https://doi.org/10.5281/ zenodo.165773. 


\section{3) Developing a Review Protocol}

Penelitian ini bermaksud mendeskripsikan pengaruh pandemic COVID-19 terhadap perilaku pengguna perpustakaan termasuk di dalamnya emosi, persepsi, sikap, respon, dsb. dalam menggunakan perpustakaan digital.

\section{b. Conducting}

Tujuan utama dari tahap ini adalah untuk mengambil, memilih dan menganalisis sumber informasi utama yang ditemukan dalam database, sesuai dengan kegiatan berikut:

\section{1) Search Strategies and Resources}

Dalam menentukan kata kunci yang akan menjawab pertanyaan penelitian RQ1, RQ2, dan RQ3 menggunakan kata kunci yang relevan dengan pertanyaan penelitian. Selain itu, untuk memperluas hasil pencarian, mengkombinasikan kata kunci dengan menggunakan persamaan kata (sinonim) seperti: User experience OR User Evaluation OR Visitor Experience. Untuk mendapatkan hasil pencarian yang spesifik, dilakukan pencarian di database menggunakan Boolean Logic AND, OR, NOT seperti Pandemic COVID-19 AND User experience; Pandemic COVID-19 AND User experience AND Digital Library; Pandemic COVID-19 AND Digital Library; User experience AND Library; User experience AND Perpustakaan.

Pencarian literatur pada penelitian ini dilakukan pada database https:// remote-lib.ui.ac.id/menu dan search engine Google Scholar. Kedua database ini dipilih dan digunakan dengan alasan kemudahan akses pencarian informasi yang dibutuhkan dengan cakupan hasil yang luas terhadap penelitian User Experience. Artikel yang diperoleh kemudian disimpan dalam reference manager Mendeley. Adapun batasan tahun literatur yang digunakan dalam penelitian ini yaitu publikasi dengan kurun waktu 2011-2021 atau 10 tahun terakhir.

Kriteria inklusi dan eksklusi dari search query ditetapkan berdasarkan kualitas literatur yang dianggap relevan dan konten literatur yang diterima dan diakui di lapangan. Berikut kriteria inklusi sebagai berikut: 1) artikel 
jurnal User Experience dengan fokus pada digital library; 2) artikel yang dipublikasikan mulai tahun 2011-2019. Sedangkan kriteria eksklusi sebagai berikut: 1) artikel jurnal di luar topik bahasan User Experience dan digital library; 2) artikel jurnal yang memiliki duplikasi dalam database; 3) artikel yang dipublikasikan sebelum tahun 2011

Strategi seleksi berdasarkan tahun terbit adalah sebagai berikut: tahun 2021 sebanyak 1 artikel, tahun 2020 sebanyak 4 artikel, tahun 2019 sebanyak 2 artikel, tahun 2017 sebanyak 3 artikel.

\section{2) Selection of primary research}

Saat melakukan pencarian literatur di database yang dipilih sesuai dengan kriteria inklusi dan eksklusi, hasilnya diekspor ke format yang kompatibel dengan Excel, hingga hasil akhir disimpan dan analisis abstrak setiap studi dapat mulai memvalidasi topik tersebut. Hasil akhir seleksi berdasarkan jenis dokumen mengacu pada PRISMA (Preferred Reporting Items for Systematic Reviews and Meta-Analysis) ditunjukkan pada Gambar 2. 


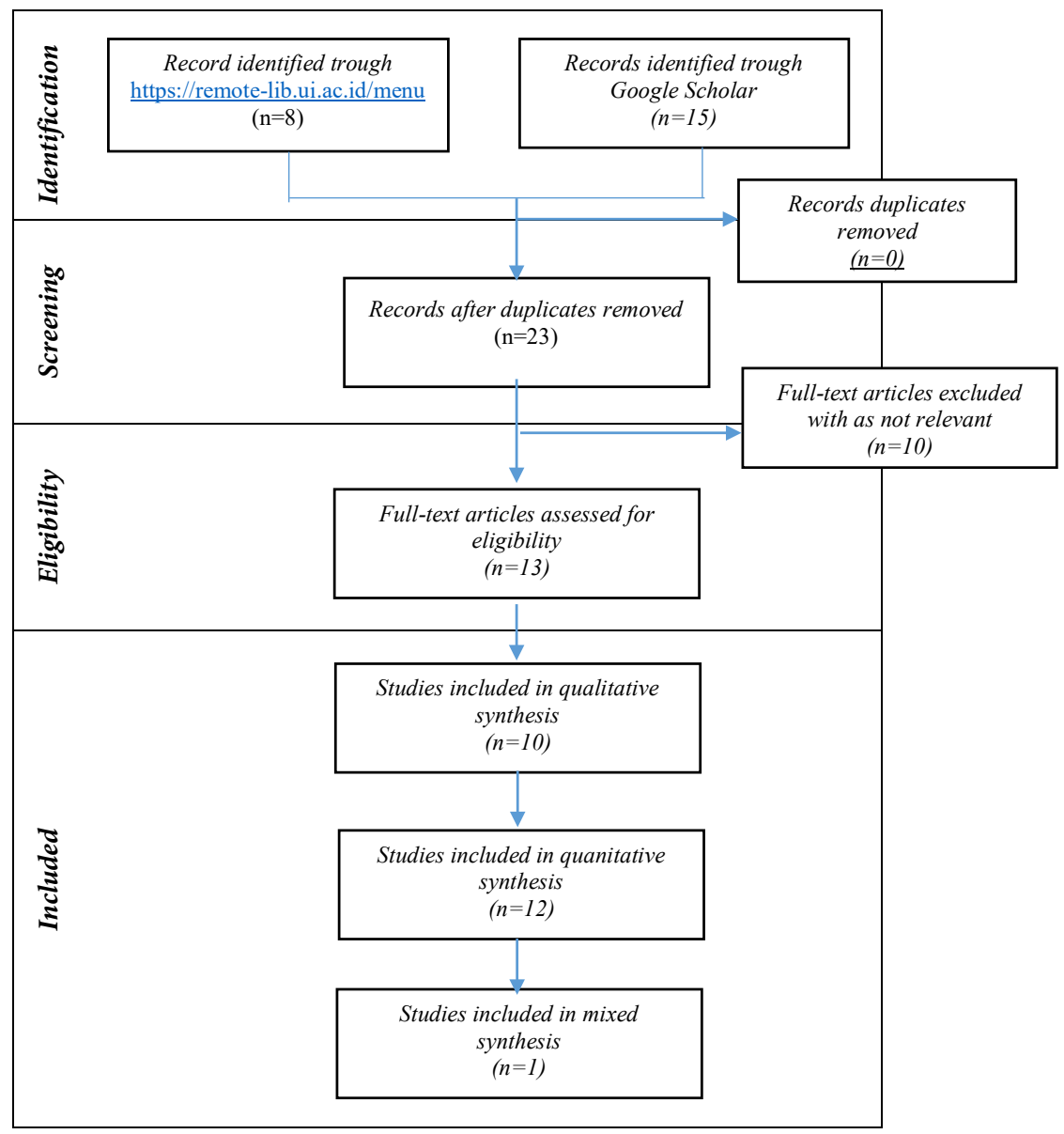

Gambar 2. Hasil Akhir Seleksi Dokumen (PRISMA)

Sumber: Shamseer et al. $(2015)^{15}$

\section{3) Quality Assessment}

Dengan menggunakan check list untuk setiap pertanyaan, dapat dievaluasi apakah penelitian dapat menjawab pertanyaan dari isi abstrak

${ }^{15}$ Larissa Shamseer, David Moher, Mike Clarke, Davina Ghersi, Alessandro Liberati, Mark Petticrew, Paul Shekelle, Lesley A Stewart, and Prisma-p Group. 2015. "Meta-Analysis Protocols ( PRISMA-P ) 2015 : Elaboration and Explanation” 7647 (February 2012): 1-25. https://doi.org/10.1136/ bmj.g7647. 
atau tidak. Penilaian ini bertujuan untuk mengevaluasi kualitas artikel dan kebermanfaatan data yang didapatkan. Setiap pernyataan memiliki tiga pilihan jawaban, yaitu: $\mathrm{Ya}=1$; Ragu-ragu $=0$; Tidak $=-1$. Kriteria penilaian kualitas dapat dilihat pada Tabel 2.

\section{Tabel 2. Kriteria Penilaian Kualitas Berdasarkan Hasil Penelusuran}

\begin{tabular}{cllc}
\hline Kriteria Kualitas & \multicolumn{1}{c}{ Item Pertanyaan } & Jawaban & Skor \\
\hline Q1 & Apakah ada deskripsi yang jelas & Tidak & 0 \\
& tentang maksud dan tujuan penelitian & Ragu-ragu & 0,5 \\
& ini? & Ya & 1 \\
Q2 & Apakah penelitian ini didasarkan pada & Tidak & 0 \\
& penelitian terdahulu? & Ragu-ragu & 0,5 \\
& & Ya & 1 \\
Q3 & Apakah penelitian ini diambil dari & Tidak & 0 \\
& suatu kasus atau laporan berdasarkan & Ragu-ragu & 0,5 \\
& pendapat ahli? & Ya & 1 \\
Q4 & Apakah penelitian ini menjelaskan & Tidak & 0 \\
& tentang User experience dan Digital & Ragu-ragu & 0,5 \\
& Library? & Ya & 1 \\
\hline
\end{tabular}

Sumber: Cruz-Benito $(2016)^{16}$

\section{4) Data Extraction and Monitoring}

Pada saat melakukan seleksi terhadap 12 literatur ditemukan: 1 tesis, 2 artikel prosiding, 10 artikel jurnal Abstrak dari setiap penelitian diperiksa untuk memilih hanya yang memenuhi kriteria kualitas dan yang terkait dengan User experience dan Digital Library.

\section{c. Reporting}

Dalam menyusun laporan, referensi penulis dicocokan dengan kode alfanumerik dalam urutan abjad untuk mengidentifikasi studi yang disertakan dalam laporan. Hasil klasifikasi penulis dan skor sebagai berikut:

${ }^{16}$ Juan Cruz-Benito. 2016. “Systematic Literature Review \& Mapping.” https://doi.org/10.5281/ zenodo. 165773 . 
kode literatur T1: 4; P1: 3; P2: 4; J1: 4; J2: 4; J3: 4; J4: 2; J5: 4; J6: 4; J7: 4; J8: 4; J9: 4; J10: 4.

\section{1) Quality Criteria Report}

Identifikasi kualitas kriteria penulisan ditunjukkan pada tabel 2 di atas pada masing-masing hasil dari 12 literatur yang ditemukan. Hasil dari representasi kriteria kualitas dapat diligat pada Gambar 3.

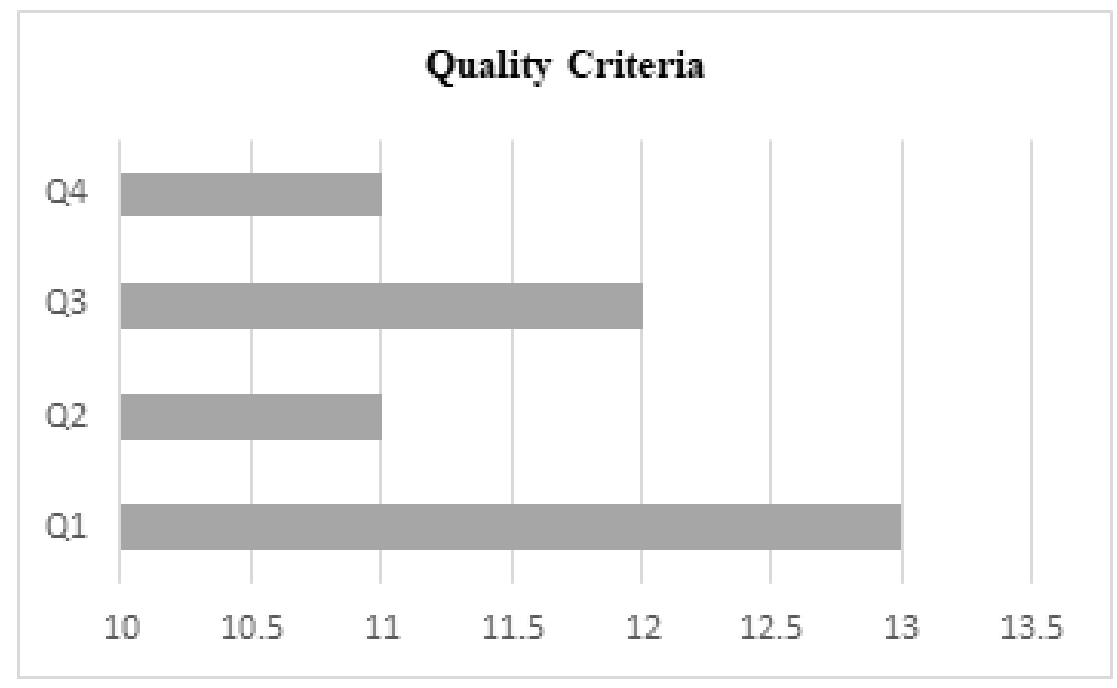

Gambar 3. Representasi Hasil Kriteria Kualitas

\section{2) Report of Type of Study}

Laporan jenis literatur berdasarkan kriteria inklusi dan ekslusi untuk kemudian dianalisis untuk mengidentifikasikan tahun, jenis publikasi, nama jurnal atau konferensi untuk menemukan di mana literatur ini dterbitkan.

\section{HASIL DAN PEMBAHASAN}

a. Dampak pandemi COVID-19 terhadap user experience

Pengalaman pengguna (emosi, persepsi, perilaku, respon) dalam menggunakan perpustakaan digital. 
Linden mengungkapkan pendekatan pengalaman pengguna muncul sebagai kerangka kerja yang komprehensif dan memberika perspektif holistik tentang respon subjektif pengguna yang timbul dari penggunaan teknologi. ${ }^{17}$ Respon pengguna mengacu pada tingkat emosional seseorang seperti kegembiraan, kekecewaan, keharuan dan kecintaan dalam menggunakan suatu produk tertentu. Selain itu, persepsi merupakan efek dari proses pengenalan dan catatan manusia, atau sebuah interpretasi empiris dari fenomena di dunia luar. ${ }^{18}$

Dari hasil penelusuran dan penilaian kualitas artikel baik jurnal, conference paper maupun tesis diperoleh beberapa respon mengenai emosi pengguna dalam menggunakan perpustakaan digital terdapat pada artikel T1, P2, J1, J7, J9. Sedangkan untuk persepsi pengguna terdapat pada artikel J2, J3, J5, J6, J8. Berikut adalah rincian dari tingkat emosi dari beberapa artikel yang telah diseleksi:

T1 : Emosi masyarakat menjadi kuat ketika menggunakan layanan digital pada pandemi COVID-19 karena urgensi untuk mendapatkan layanan berkualitas tinggi telah meningkat. Dari hasil penelitian ini, emosi yang ditemukan adalah keinginan untuk mengendalikan, mengkritik, dan kebutuhan untuk memanfaatkan platform digital untuk keperluan pribadi. Emosi tersebut berbeda sebelum pandemi karena mereka lebih kuat dan kurang positif. Dengan demikian platform digital yang dapat menyediakan sesuatu yang dapat mengendalikan perasaan dengan berbagai pilihan yang akan memenangkan hati para pengguna.

P2: Dalam artikel ini ditemukan bahwa suasana hati yang erat kaitannya dengan emosi dapat berubah selama tahap pencarian informasi

${ }^{17}$ Jan Van Der Linden and others 2019. "User Experience and Social Influence: A New Perspective for UX Theory." Lecture Notes in Computer Science (Including Subseries Lecture Notes in Artificial Intelligence and Lecture Notes in Bioinformatics) 11583 LNCS: 98-112. https://doi. org/10.1007/978-3-030-23570-3_9.

${ }^{18}$ Krystyna K. Matusiak. 2012. "Perceptions of Usability and Usefulness of Digital Libraries." International Journal of Humanities and Arts Computing 6 (1-2): 133-47. https://doi.org/10.3366/ ijhac.2012.0044. 
yaitu diawal, tengah dan akhir pencarian. Emosi negatif, khususnya ketidakpastian dan frustasi dialami pada awal dan pertengahan pencarian informasi dan diakhir pencarian merasa puas dan lega. Selain itu, dengan menganalisis alasan dibalik suasana hati yang tidak menyenangkan, ditemukan bahwa alasan pribadi dan faktor digital library termasuk konten dan kegunaan memainkan peran pening di balik suasana hati yang tidak menyenangkan.

Berdasarkan hasil rincian beberapa artikel tersebut di atas dapat dikatakan bahwa, emosi seseorang dalam menggunakan platform digital terutama perpustakaan digital akan mempengaruhi hasil akhir dari penggunaan platform tersebut. Seperti yang dideskripsikan pada artiket P2, emosi dapat berubah selama tahap pencarian, oleh karena itu ketika seseorang mudah menemukan informasi yang dicari secara otomatis hal tersebut akan menjadi pengalaman yang menyenangkan bagi pengguna perpustakaan.

Berikut adalah rincian persepsi dari beberapa artikel yang telah diseleksi:

J2 : Studi ini menemukan bahwa persepsi pengguna tentang keuntungan dan kegunaan, terutama persepsi kemudahan penggunaan, memainkan peran penting dalam niat pengguna untuk mengadopsi dan menggunakan koleksi digital untuk pembelajaran akademik dan pengajaran.

J6 : Artikel ini memuat kajian tentang digital library dan user experience dari beberapa pakar, diantaranya Xianjin dalam Thaker dimana membandingkan persepsi pengguna dengan perpustakaan seluler dan perpustakaan digital sehubungan dengan flow experience yang didefinisikan sebagai pengalaman terbaik tentang suatu aktivitas yang dapat dilakukan dengan membandingkan tantangan yang dirasakan.

Persepsi pengguna terhadap perpustakaan digital dapat diketahui ketika mereka menggunakan platform perpustakaan hingga mereka menemukan informasi yang dibutuhkan. Ketika pengguna berhenti 
melakukan pencarian informasi di tengah-tengah pencarian dan tidak melanjutkan pencarian, perpustakaan perlu melakukan evaluasi terhadap platform perpustakaan digital tersebut.

Hal yang mempengaruhi pengguna menggunakan perpustakaan digital selama pandemi.

Dalam artikel Moreira disebutkan pandemi telah mengubah cara pengguna menggunakan platform dan layanan digital, layanan ini telah menjadi inti dari bagaimana orang berinteraksi dengan dunia luar. Orangorang bekerja secara online, lebih sering berbelanja acara online, dan berkomunikasi serta menghibur secara online dengan cepat. ${ }^{19}$ Dari hasil penelusuran literatur dan penilian kualitas terkait pertanyaan penelitian, tidak banyak ditemukan artikel yang relevan dengan topik. Terdapat 2 (dua) artikel terkait topik bahasan dampak pandemi COVID-19 terhadap terhadap User Experience dalam menggunakan platform digital yaitu T1, J9 dan J10. Menurut Stephen Watts dalam (Moreira 2021) yang termasuk platform digital meliputi: media sosial (facebook, instagram, twitter, linkedin); platform pengetahuan dan pembelajaran (StackOverflow, Quora, Moodle dan Yahoo! Answers); media sharing (YouTube, Spotify dan Vimeo); dan berorientasi layanan (Uber, Airbnb, dan GrubHub). Digital library yang berorientasi pada layanan adalah yang menyediakan akses informasi serta konten digital dalam bentuk web responsive. Berikut rincian faktor-faktor yang mempengaruhi pengguna menggunakan platform digital selama pandemi:

T1 : Hasil penelitian menyebutkan hal-hal yang mempengaruhi pengguna menggunakan platform digital: 1) kebutuhan mengakses platform digital untuk bekerja. Hasil teratas penggunaan platform digital ini ada pada media sosial terutama bagi mereka yang menggunakan media sosial sebagai sumber pendapatan; 2) terkait dengan dorongan menggunakan platform digital selama pandemi dimana pergeseran gaya hidup online dapat mengurangi kesabaran seseorang dalam menggunakan platform digital tidak terlalu mempengaruhi pengguna

${ }^{19}$ Inna Narciso Moreira. 2021. “The Impact of the COVID-19 Pandemic on User Experience Design of Digital Platforms." 
untuk beralih ke platform yang lebih baru dan cepat; 3) kebiasaan hidup secara online mempengaruhi tingkat ketergantungan pada platform digital terutama kaitannya dengan pencapaian tugas sehari-hari; 4) Akses penggunaan platform digital meningkat setelah pandemi, meskipun platform digital yang digunakan sama dengan sebelum pandemi. Selama pandemi, jumlah konten digital juga meningkat namun banyak juga ditemukan konten palsu, hal ini diperparah dengan tingkat pemikiran kritis dan rasional yang menurun sehingga banyak pengguna percaya konten palsu yang membanjiri platform media sosial yang pada akhirnya berdampak negative bagi kesehatan mental; 5) Selama pandemi, banyak orang memutuskan koneksi dari media sosial dikarenakan keamanan data dan privacy pengguna yang meningkat selama pandemic; 6) Terkait keamanan data dan privacy, mayoritas masyarakat mulai peduli dengan keamanan data dan informasi yang dibagikan secara online namun masih ditemukan sebagian mereka tidak membaca ketentuan penggunaan aplikasi dan situs web yang mereka gunakan.

J10: Krisis COVID-19 telah membawa perpustakaan digital menjadi pusat perhatian melalui banyak manfaat yang ditawarkan, yang di masa lalu tidak terlihat atau tidak ada. Dalam hal ini, perpustakaan perlu menyadari kondisi pandemi sebagai situasi krisis dan harus beradaptasi dengan menyediakan layanan dalam format digital dan mengeksplorasi inisatif untuk mendukung pembelajaran secara online. Temuan penelitian ini, menyadarkan perpustaaan untuk untuk diimplementasikan kedalam bentuk digital dan memberikan layanan digital kepada penggunannya.

Berdasarkan deskripsi tersebut di atas, dapat dikatakan bahwa situasi krisis pandemi yang menyebabkan perpustakaan menutup aksesnya telah mendorong pengguna perpustakaan menggunakan perpustakaan digital dan mereka telah beradaptasi menggunakan platform digital untuk memenuhi kebutuhannya. 


\section{b. Kebutuhan pengguna saat ini terhadap perpustakaan digital dibandingkan sebelum masa pandemi.}

Sebelum pandemi, desain layanan platform digital berorientasi pada kebutuhan pengguna, perlahan-lahan berjalan maju, banyak perusahan mencatat bahwa penyusunan strategi. User experience adalah salah satu investasi terbaik yang dapat dilakukan agar produk dikenal di pasar dan mampu mengumpulkan khalayak banyak. Desain User experience/User Interface muncul dikarenakan ada permintaan untuk proses membangun keterlibatan pengguna yang akan menarik minat dan membuat pelanggan senang menggunakan platform digital. ${ }^{20}$

Dari hasil penelusuran literatur dan penilaian kualitas terkait pertanyaan penelitian mengenai kebutuhan pengguna terhadap perpustakaan digital sebelum dan sesudah masa pandemi terlihat dalam artikel T1 dan J10 berikut:

T1 : Sebelum pandemi, masyarakat lebih banyak mengakses informasi melalui website dan Google. Meskipun konten-konten digital telah bermunculan pada tahun 20019, namun sejak pandemi pembuat konten ramai bermunculan. Keberadaan algoritma pada platform digital menjadi penentu navigasi platform digital untuk mudah dikenali dan bahkan menjadikan viral tanpa ada pemerikasaan kelayakan konten. Pengguna lebih menyukai konten yang seperti ini dan terlepas pada kebenaran dan kenyataan yang salah., reputasi platform digital dipertanyakan sebagai sumber informasi yang andal. Ketika pandemi platform digital mengalami ledakan konten palsu, berita palsu, informasi yang salah dan kadang menyakitkan, namun banyak digunakan karena kemudahannya dalam menggunakan platform tersebut. Hal ini menyebabkan kepanikan, peristiwa tragis terjadi dan fenomena kejadian di masyarakat terjadi bergantian secara terus menerus. Akibatnya banyak orang menyebarkan

${ }^{20}$ Inna Narciso Moreira. 2021. “The Impact of the COVID-19 Pandemic on User Experience Design of Digital Platforms.” 
ujaran-ujaran kebencian secara online yang meningkat sejak awal pandemi. Menghadapi situasi tersebut, banyak perusahaan mencoba memperbaiki platform digitalnya. Kemampuan untuk mengembalikan kepercayaan pelanggan terletak pada desain User experience yang baik. Desain User experience dan kontekstual belum siap menghadapi perubahan akhibat dari pandemi, satu-satunya yang telah diprediksi adalah perubahan generasi dalam menggunakan teknologi. Sebagai akibat dari pandemi tersebut, harus dikembangkan desain User Interface yang berpusat pada pengguna.

J10: Dalam penelitian ini disebutkan sebelum pandemi, layanan referensi diberikan secara langsung daripada secara virtual. Sangat sedikit pengguna perpustakaan yang mengajukan pertanyaan dengan memanfaatkan virtual reference. Sejak pandemi, dikarenakan adanya aturan bekerja dari rumah, perpustakaan mulai menggunakan virtual reference. Dari hasil statistik dalam penelitian ini disebutkan bahwa pandemi telah menciptakan kesadaran dan penggunaan layanan virtual reference perpustakaan.

Kondisi pandemi COVID-19 telah mendorong maraknya kontenkonten digital bermunculan, berita palsu dan penyebaran informasi palsu menjadi semakin massive dan dipertanyakan kebenarannya. Dalam kondisi tersebut, kebiasaan masyarakat telah berubah dengan penggunaan platform digital dimana mereka lebih waspada terhadap penipuan dan lebih berhatihati dalam menggunakan platform digital terutama ketika mereka diharuskan melampirkan informasi pribadi pada saat hendak melakukan registrasi pada platform digital. Selain itu, semakin pengguna perpustakaan yang melakukan virtual reference untuk menjawab kebutuhan informasinya.

\section{KESIMPULAN}

Berdasarkan hasil tinjauan literature yang telah dilakukan, dapat disimpulkan bahwa dampak pandemi COVID-19 terhadap perpustakaan digital saat masa krisis telah menjadi perhatian utama bagi penggunanya 
dengan berbagai manfaat yang ditawarkan yang sebelumnya belum ada. Pengalaman pengguna (User Experience) dalam menggunakan platform digital, termasuk di dalamnya penggunaan perpustakaan digital diketahui telah dipengaruhi oleh emosi, dimana emosi pengguna menjadi lebih kuat ketika menggunakan platform digital pada pandemi COVID-19 karena urgensi untuk mendapatkan layanan berkualitas tinggi telah meningkat. Selain itu diketahui bahwa persepsi penggunaan perpustakaan digital memainkan peran penting dalam niat pengguna dalam mengadopsi dan menggunakan koleksi digital untuk pembelajaran dan pengajaran. Penelitian mengenai pengalaman pengguna pada perpustakaan digital terutama yang berfokus pada situasi pandemi COVID-19 masih belum banyak dilakukan sehingga peneliti harus mencari referensi pendukung yang sesuai dengan topik tersebut. Adapun rekomendasi dari penelitian ini adalah perlu dilakukan penelitian lanjutan dengan pendekatan kuantitatif untuk mendapatkan data yang valid.

\section{DAFTAR PUSTAKA}

Barifah, Maram, Monica Landoni, and Ayman Eddakrouri. 2020. "Evaluating the User Experience in a Digital Library." Proceedings of the Association for Information Science and Technology 57 (1): 1-17. https://doi.org/10.1002/pra2.280.

Bevan, Nigel, James Carter, and Susan Harker. 2015. "Iso 9241-11 Revised: What Have We Learnt about Usability since 1998?” Lecture Notes in Computer Science (Including Subseries Lecture Notes in Artificial Intelligence and Lecture Notes in Bioinformatics) 9169: 143-51. https:// doi.org/10.1007/978-3-319-20901-2 13.

Cruz-Benito, Juan. 2016. "Systematic Literature Review \& Mapping." https:// doi.org/10.5281/zenodo.165773. (3)

Hariri, Nadjla, and Yaghoub Norouzi. 2011. "Determining Evaluation Criteria for Digital Libraries’ User Interface: A Review.” Electronic Library 29 (5): 698-722. https://doi.org/10.1108/02640471111177116. 
IFLA. 2011. "UNESCO Endorses the IFLA Manifesto for Digital Libraries." 2011. https://www.ifla.org/news/unesco-endorses-the-ifla-manifestofor-digital-libraries/

Linden, Jan Van Der, Franck Amadieu, Emilie Vayre, and Cécile Van De Leemput. 2019. "User Experience and Social Influence: A New Perspective for UX Theory." Lecture Notes in Computer Science (Including Subseries Lecture Notes in Artificial Intelligence and Lecture Notes in Bioinformatics) 11583 LNCS: 98-112. https:/doi. org/10.1007/978-3-030-23570-3_9. (4)

Matusiak, Krystyna K. 2012. "Perceptions of Usability and Usefulness of Digital Libraries." International Journal of Humanities and Arts Computing 6 (1-2): 133-47. https://doi.org/10.3366/ijhac.2012.0044.

Mehta, Dipti, and Xiaocan Wang. 2020. "COVID-19 and Digital Library Services - a Case Study of a University Library." Digital Library Perspectives 36 (4): 351-63. https://doi.org/10.1108/DLP-05-20200030.

Moreira, Inna Narciso. 2021. "The Impact of the COVID-19 Pandemic on User Experience Design of Digital Platforms."

Sasongko, Dimas, Ridi Ferdiana, and Rudy Hartanto. 2016. “The Development of Digital Library User Interface by Using Responsive Web Design and User Experience." Indonesian Journal of Electrical Engineering and Computer Science 4 (1): 195-202. https://doi.org/10.11591/ijeecs. v4.i1.pp195-202.

Shamseer, Larissa, David Moher, Mike Clarke, Davina Ghersi, Alessandro Liberati, Mark Petticrew, Paul Shekelle, Lesley A Stewart, and Prisma-p Group. 2015. "Meta-Analysis Protocols ( PRISMA-P) 2015 : Elaboration and Explanation” 7647 (February 2012): 1-25. https:// doi.org/10.1136/bmj.g7647.

Thaker, Kinnery, and Pratiksinh S. Vaghela. 2017. "Digital Library and User's Experience: A Literature Review." Scientific Society of Advanced Research and Social Change SSARSC International Journal of Library, 
Information Networks and Knowledge 2 (1): 1-8.

Wahono, Romi Satria. 2015. "Systematic Literature Review ( SLR )."

Xie, Iris, and Krystyna K. Matusiak. 2016. Discover Digital Libraries: Theory and Practice. Discover Digital Libraries: Theory and Practice. 